\title{
Pengaruh Pupuk Hayati dan Konsentrasi Pupuk Pelengkap Alkalis terhadap Respirasi Tanah pada Pertanaman Bawang Putih (Allium sativum L.) Ketinggian 600 mdpl di Kabupaten Tanggamus.
}

\author{
Dina Yuliana ${ }^{1}$, Sri Yusnaini ${ }^{2}$, Kus Hendarto ${ }^{2}$, dan Ainin Niswati ${ }^{2}$ \\ ${ }^{1}$ Mahasiswa Jurusan Agroteknologi Fakultas Pertanian Universitas Lampung \\ ${ }^{2}$ Dosen Jurusan Agroteknologi Fakultas Pertanian Universitas Lampung \\ Bandar Lampung 32145 \\ Email: dinayulianaaa28@gmail.com
}

\begin{abstract}
ABSTRAK
Respirasi tanah merupakan indikator penting pada suatu ekosistem, meliputiseluruh aktivitas yang berkenaan dengan proses metabolisme di dalam tanah,dekomposisi sisa tanaman dalam tanah, dan konversi bahan organik tanah menjadi $\mathrm{CO}_{2}$. Banyak usaha untuk meningkatkan laju respirasi tanah, salah satunya adalah dengan pemupukan.Pemupukan menggunakan pupuk hayati serta pupuk pelengkap alkalis diharapkan mampu meningkatkan aktivitas mikroorganisme didalam tanah. Penelitian bertujuan untuk mempelajari pengaruh pemberian pupuk hayati dan pupuk pelengkap alkalis terhadap respirasitanah. Penelitian dilaksanakan di Desa Dadapan, Kecamatan Sumberejo, KabupatenTanggamus, pada bulan Desember 2016 - Mei 2017 dengan menggunakan Rancangan Acak Kelompok (RAK) faktorial yang terdiri dari dua faktor, yaitu pemberian pupuk hayati (Bio Max Grow) terdiri dari perlakuan tanpa pupuk hayati $\left(\mathrm{B}_{0}\right)$ dan diberi pupuk hayati $\left(\mathrm{B}_{1}\right)$, dan perlakuan konsentrasi pupuk pelengkap (Plant Catalyst)terdiri dari perlakuan tanpa pupuk pelengkap $\left(\mathrm{P}_{0}\right)$, konsentrasi 0,5 g L $\mathrm{L}^{-1}\left(\mathrm{P}_{1}\right)$, $1 \mathrm{gL}^{-1}\left(\mathrm{P}_{2}\right)$ dan 1,5 $\mathrm{g} \mathrm{L}^{-1}\left(\mathrm{P}_{3}\right)$. Data yang diperoleh diujihomogenitas ragamnya dengan uji Bartlett dan aditivitasnya dengan uji Tukey. Data dianalisis dengan ANARAdan dilanjutkan dengan uji BNT pada taraf $5 \%$. Hasil penelitian menunjukkan bahwa pupuk hayati, pupuk pelengkap dan interaksi keduanya berpengaruh terhadap respirasi tanah pada pengamatan 45 HST, tetapi tidak berpengaruh pada pengamatan $90 \mathrm{HST}$. Perlakuan pupuk hayati + pupuk pelengkap dengan konsentrasi $1 \mathrm{~g} \mathrm{~L}^{-1}\left(\mathrm{~B}_{1} \mathrm{P}_{2}\right)$ menghasilkan laju respirasi tertinggi yaitu 63,69 $\mathrm{mg} \mathrm{jam}^{-1} \mathrm{~m}^{-}$ 2 pada pengamatan 45 HST. Tidak terdapat korelasi antara C-organik tanah, kadar air tanah, serta suhu tanah dengan respirasi tanah. Terdapat korelasi negatif antara $\mathrm{pH}$ tanah dengan respirasi tanah pada pengamatan 45 HST, artinya semakin tinggi $\mathrm{pH}$ tanah maka respirasi tanah semakin rendah
\end{abstract}

Kata kunci: Bio Max Grow, Respirasi tanah, Plant Catalyst.

\section{PENDAHULUAN}

Bawang putih (Allium sativum L.) merupakan salah satu komoditas hortikultura yang banyak digunakan sebagai bumbu dasar masakan dan obat tradisional, hal inilah yang menyebabkan tingginya permintaan pasar. Menurut Badan Pusat Statistik
(2017), rata-rata konsumsi bawang putih di Indonesia terus meningkat dari periode 2013 hingga 2015, namun peningkatan konsumsi ini tidak sejalan dengan luas panen bawang putih. Menurut Sarwadana dan Gunadi (2007), sentra produksi bawang putih umumnya di dataran tinggi, karena varietas-varietas yang ada 
kebanyakan hanya cocok ditanam antara 700-1.100 $\mathrm{m}$ di atas permukaan laut (dataran tinggi). Dengan keterbatasan faktor tumbuh bawang putih, yang lainnya dapat tumbuh di dataran tinggi menyebabkan wilayah dataran rendah tidak menjadi sentra produksi.

Selain penurunan luas panen faktor lain seperti rendahnya kesuburan tanah dapat menurunkan produksi bawang putih. Untuk menghasilkan produksi bawang putih tinggi maka perlu dilakukan pemupukkan pada lahan budidaya tanaman bawang putih. Pupuk yang sebaiknya digunakan adalah pupuk pelengkap yang mengandung unsur hara makro dan mikro serta pupuk hayati yang ramah lingkungan. Dalam hal ini pupuk pelengkap yang dapat digunakan ialah Plant Catalyst. Pupuk pelengkap Plant Catalyst mengandung unsur hara makro dan mikro yang dibutuhkan tanaman agar tumbuh sehat.

Adapun unsur hara makro yang terkandung dalam pupuk pelengkap Plant Catalyst adalah N, P, $\mathrm{K}, \mathrm{Ca}, \mathrm{Mg}$ dan S, sedangkan unsur hara mikro yang terkandung dalam pupuk pelengkap Plant Catalyst adalah Fe, Cl, Mn, Cu, Zn, Bo dan Mo (PT Citra Nusa Insan Cemerlang, 2014). Pupuk hayati juga dapat didefinisikan sebagai suatu hasil produksi pupuk yang mengandung sel-sel mikroorganisme yang dapat menambah $\mathrm{N}$, pelarut $\mathrm{P}, \mathrm{S}$ oksidan atau pengurai bahan organik. Pupuk hayati secara singkatnya dapat disebut sebagai inokulan bio yang pada asupan ke tanaman dapat meningkatkan pertumbuhan dan hasil tanaman (Khan dkk., 2011).

Pemberian pupuk pelengkap (Plant catalyst) yang mengandung unsur hara makro dan mikro serta penambahan pupuk hayati (Bio max grow) akan memperbaiki sifat fisik, kimia dan biologi tanah. Adanya pupuk pelengkap Plant Catalyst dan pupuk hayati Bio Max Growakan memperbaiki kehidupan mikroorganisme di dalam tanah sehingga terjaga dengan baik. Kehidupan mikroorganisme yang baik dapat ditunjukkan dengan meningkatnya laju respirasi tanah.

Respirasi tanah merupakan indikator penting pada suatu ekosistem, meliputi seluruh aktivitas yang berkenaan dengan proses metabolisme di dalam tanah,dekomposisi sisa tanaman dalam tanah, dan konversi bahan organik tanah menjadiCO $\mathrm{CO}_{2}$. Respirasi tanah menggambarkan aktivitas mikroorganisme tanah.Respirasitanah adalah proses hilangnya $\mathrm{CO}_{2}$ dari tanah ke atmosfer, terutama yang dihasilkan oleh mikroorganisme tanah dan akar tanaman. Hal ini dipengaruhi tidak hanya oleh faktor biologis seperti vegetasi dan faktor lingkungan, antara lain suhu, kelembaban, $\mathrm{pH}$, tetapi juga lebih kuat oleh faktor buatan manusia (Fang dkk., 1998).

Penelitian ini bertujuanuntukmengetahuipenganuh perlakuan pupuk hayati Bio Max Grow, pupuk pelengkap Plant Catalyst dan interaksi antara kedua pupuk tersebut terhadap respirasi tanah pada pertanaman bawang putih (Allium sativum L.).

\section{BAHAN DAN METODE}

Lokasi penelitian dilakukan di Desa Dadapan ketinggian 600 mdpl, Kecamatan Sumberejo, Kabupaten Tanggamus. Penelitian ini dilakukan dari bulan Desember 2016 sampai dengan bulan Mei 2017 untuk pengamatan di lapang dan dari bulan Desember 
2016 sampai bulan April 2017 untuk pengamatan di laboratorium Universitas Lampung.

Bahan- bahan yang digunakan dalam penelitian ini adalah Benih bawang putih varietas Tawangmangu, pupuk hayati (Bio Max Grow), pupuk pelengkap (Plant Catalyst), SP-36, Urea, Ponska, KCl, serta bahan kimia untuk analisis respirasi tanah. Sedangkan alat - alat yang digunakan dalam penelitian ini adalah cangkul, mulsa jerami, selang air, meteran, ember, ayakan tanah $10 \mathrm{~mm}$, oven, gelas ukur $100 \mathrm{ml}$, sprayer, selang air, soil temperature (pengukur suhu tanah), botol film $20 \mathrm{ml}$, labu ukur $1000 \mathrm{ml}$, Erlenmeyer 100 $\mathrm{ml}$, alat tulis, dan alat-alat laboratorium lainnya untuk analisis respirasi tanah dan sampel tanah.

Penelitian ini dilaksanakan dengan menggunakan Rancangan Acak Kelompok (RAK) yang disusun secara faktorial. Faktor pertama dosis pupuk hayati Bio Max Grow (B) dan faktor kedua konsentrasi pupuk pelengka Plant Catalyst (P). Faktor pertama terdiri dari dua taraf yaitu $\mathrm{B}_{0}=\tan \mathrm{pa}$ pupuk hayati Bio Max Grow dan $\mathrm{B}_{1}=$ menggunakan pupuk hayati Bio Max Grow. Faktor kedua terdiri dari empat taraf yaitu $\mathrm{P}_{0}=$ tanpa pupuk pelengkap Plant Catalyst, $\mathrm{P}_{1}=0,5 \mathrm{~g} \mathrm{~L}^{-1}, \mathrm{P}_{2}=1 \mathrm{~g} \mathrm{~L}^{-1}, \mathrm{P}_{3}=1,5 \mathrm{~g} \mathrm{~L}^{-1}$. Setiap perlakuan diulang sebanyak tiga kali sehingga diperoleh 24 petak satuan percobaan.

Homogenitas ragam dilakukan dengan Uji Bartlett dan kenambahan data diuji dengan Uji Tukey. Setelah asumsi terpenuhi data diolah dengan analisis ragam pada taraf nyata 5\% dan diuji lanjut dengan uji beda nyata terkecil (BNT) 5\%, untuk mengetahui hubungan antara respirasi tanah dengan kadar air tanah,
pH tanah, C-organik tanah, dan suhu tanah dilakukan dengan uji korelasi.

\section{Variabel Utama}

Respirasi Tanah. Pengukuran respirasi tanah dilapang diukur pada awal (sebelum aplikasi perlakuan), saat tanaman berumur 45 hari, dan saat tanaman bawang putih panen. Respirasi tanah diukur dengan metode modifikasi Verstraete (Anas, 1989) yaitu dengan menutup permukaan tanah menggunakan toples yang didalamnya telah diberikan botol film yang berisi $10 \mathrm{ml} \mathrm{KOH}$ dan $10 \mathrm{ml}$ aquades, untuk kontrol dilakukan hal yang sama, tetapi tanah ditutup dengan plastik terlebih dahulu sehingga $\mathrm{KOH}$ tidak dapat menangkap $\mathrm{CO}_{2}$ yang keluar dari tanah, dan pengukuran ini dilakukan selama 2 jam. Jumlah $\mathrm{CO}_{2}$ dihitung dengan menggunakan rumus :

$$
\mathrm{C}-\mathrm{CO}_{2}=\frac{(\mathrm{a}-\mathrm{b}) \times \mathrm{t} \times 12}{\mathrm{~T} \times \pi \times \mathrm{r}^{2}}
$$

Keterangan :

$\mathrm{C}-\mathrm{CO}_{2}=\mathrm{mg} \mathrm{jam}^{-1} \mathrm{~m}^{-2}$

a $\quad=\mathrm{ml} \mathrm{HCl} \mathrm{untuk} \mathrm{sampel} \mathrm{(setelah} \mathrm{ditambahkan}$ metyl orange)

$\mathrm{b}=\mathrm{ml} \mathrm{HCl} \mathrm{untuk} \mathrm{blanko} \mathrm{(setelah} \mathrm{ditambahkan}$ metyl orange)

$\mathrm{t}=$ normalitas $(N) \mathrm{HCl}$

$\mathrm{T}=\operatorname{waktu}($ jam $)$

$\mathrm{r} \quad=$ jari-jari tabung toples $(\mathrm{m})$

\section{Variabel Pendukung.}

Variabel pendukung yang diamati yaitu kadar air tanah, $\mathrm{pH}$ tanah, suhu tanah, dan C-organik tanah yang dilakukan pada saat umur 45 hari setelah tanam dan 90 hari setelah tanam (saat panen). 


\section{HASIL DAN PEMBAHASAN}

Hasil analisis ragam (Tabel 1), menunjukan bahwa perlakuan pupuk hayati dan pupuk pelengkap serta interaksi antara keduanya pada 45 HST memberikan pengaruh yang nyata terhadap respirasi tanah, sedangkan pada 90 HST tidak memberikan pengaruh nyata baik pada perlakuan pupuk hayati, pupuk pelengkap dan interaksi antara keduanya.

Perlakuan pupuk hayati $\left(\mathrm{B}_{1}\right)$ memberikan pengaruh nyataterhadap respirasi tanah pada pengamatan 45 HST. Pada perlakuan pupuk hayati $\left(\mathrm{B}_{1}\right) 10 \mathrm{ml} \mathrm{L}^{-1}$ menghasilkan respirasi tanah yang lebih tinggi dibandingkan dengan tanpa pupuk hayati, hal ini diduga karena kandungan mikroba yang terdapat pada pupuk hayati yaitu Azospirillium sp., Azobacter sp., Lactobacillus sp., Mikroba pelarut fosfat, Mikroba selulotik, Pseudomonas sp., Indole Acetis Acid Hormone, Enzim Alkaline Fosfatase, Enzim Active
Fosfatase(Gunarto, 2015), sehingga adanya pemberian pupuk hayati Bio Max Grow dapat meningkatkan populasi dan aktivitas mikroorganisme sehingga laju respirasi akan meningkat.

Pengamatan 90 HST tidak memberikan pengaruh nyata terhadap respirasi tanah, hal ini diduga karena pemberian pupuk hayati hanya diberikan pada 3 dan 5 MST dan pada saat tanaman bawang putih berumur 7 MST terkena penyakit, lalu dilakukan penyemprotan fungisida, sehingga populasi mikroorganisme dalam tanah menurun yang mengakibatkan aktivitas aktivitas mikroorganisme menurun. Menurunnya aktivitas mikroorganisme, akan menurunkan laju respirasi tanah. Hal ini dikarenakan respirasi tanah merupakan gambaran dari aktivitas mikroorganisme dalam tanah.

Berdasarkan Uji BNT 5\% (Tabel 2), menunjukan bahwa pemberian pupuk hayati

Tabel 1. Ringkasan Analisis Ragam Pengaruh Perlakuan Pupuk Hayati dan Pupuk Pelengkap terhadap Respirasi Tanah pada 45 HST dan 90 HST pada Pertanaman Bawang Putih (Alliumsativum L.).

\begin{tabular}{ccc}
\hline Sumber Keragaman & \multicolumn{2}{c}{ F Hitung dan Signifikasi } \\
\cline { 2 - 3 } & 45 HST & 90 HST \\
\hline B & $17,26^{*}$ & $0,30^{\text {th }}$ \\
P & $31,06^{*}$ & $1,96^{\text {th }}$ \\
B x P & $15,84^{*}$ & $2,17^{\text {tn }}$ \\
\hline
\end{tabular}

Keterangan : *=nyata; tn=tidak nyata; HST=Hari Setelah Tanam; B=Bio Max Grow; $\mathrm{P}=$ Plant Catalyst.

Tabel 2. Pengaruh Pupuk Hayati terhadap Respirasi Tanah pada Pertanaman Bawang Putih 45 HST.

\begin{tabular}{lc}
\multicolumn{1}{c}{ Perlakuan } & $\begin{array}{c}\text { Respirasi } \\
\text { C-CO2 }\left(\mathrm{mg} \mathrm{jam}^{-1} \mathrm{~m}^{-2}\right)\end{array}$ \\
\hline Tanpa Pupuk Hayati Bio Max Grow $\left(\mathrm{B}_{0}\right)$ & $31,52 \mathrm{~b}$ \\
Pupuk Hayati Bio Max Grow $\left(\mathrm{B}_{1}\right)$ & $39,48 \mathrm{a}$ \\
\hline BNT $(0,05)$ & 4,11 \\
\hline
\end{tabular}

Keterangan: Angka yang diikuti oleh huruf kecil yang sama tidak berbeda nyata dengan uji BNT pada taraf $5 \%$. 
$\left(B_{1}\right)$ menghasilkan respirasi tanah yang lebih tinggi dibandingkan dengan perlakuan tanpa pupuk hayati, perlakuan $\mathrm{B}_{1}$ berbeda dengan perlakuan $\mathrm{B}_{0}$, hal ini diduga karena kandungan yang terdapat pada pupuk hayati seperti Azospirillium sp.,Azobacter sp., Lactobacillus sp., Mikroba pelarut fosfat, Mikroba selulotik, Pseudomonas sp. Sehingga meningkatkan aktivitas mikroorganisme dan Laju respirasi tanah. Menurut Hanafiah (2005), Respirasi tanah merupakan pencerminan aktivitas mikroorganisme tanah.

Berdasarkan Uji BNT 5\% (Tabel 3), menunjukan bahwa konsentrasi pupuk pelengkap menghasilkan nilai respirasi lebih tinggi pada perlakuan dengan konsentrasi0,5 $\mathrm{gL}^{-1}\left(\mathrm{P}_{1}\right), 1 \mathrm{gL}^{-1}\left(\mathrm{P}_{2}\right)$, dan 1,5 $\mathrm{gL}^{-1}\left(\mathrm{P}_{3}\right)$, dibandingkan dengan tanpa pupuk pelengkap $0 \mathrm{gL}^{-1}\left(\mathrm{P}_{3}\right)$. Hal ini diduga karena kandungan yang terdapat pada pupuk pelengkap Plant Catalyst yaitu unsur hara makro (N, P, K, Ca, Mg, S) dan mikro (Fe, $\mathrm{Cu}, \mathrm{Co}, \mathrm{Zn}, \mathrm{Mn}, \mathrm{Na}, \mathrm{Cl}, \mathrm{B}$ dan $\mathrm{Mo}$ ) yang dibutuhkan oleh mikroorganisme sebagai sumber makanan sehingga semakin banyak unsur haramaka aktivitas mikroorganisme akan meningkat. Menurut
Hajoeningtijas (2005), mikroorganisme membutuhkan sumber nutrisi dari unsur-unsur dasar seperti karbon, nitrogen, hidrogen, oksigen, sulfur, fosfor, dan zat besi, serta membantu dalam penyerapanunsur hara Interaksi pupuk hayati dan pupuk pelengkap Plant Catalyst terbaik yaitu Perlakuan tanpa pupuk hayati yang memberikan hasil respirasi tanah tertinggi yaitu pada konsentrasi pupuk pelengkap $1 \mathrm{~g} \mathrm{~L}^{-1}$, hal ini diduga karena tidak ada pemberian pupuk hayati sehingga jumlah mikroorganisme tanah tidak bertambah, oleh sebab itu mikroorganisme yang sudah ada di dalam tanah membutuhkan asupan sumber energi untuk keberlangsungan hidup dengan memberikan konsentrasi pupuk pelengkap $1 \mathrm{~g} \mathrm{~L}^{-1}$ sudah mampu menyediakan unsur hara, karena pupuk pelengkap mengandung unsur hara makro dan mikro sehingga keberlangsungan hidup mikroorganisme tanah meningkat.

Perlakuan pemberian pupuk hayati respirasi tertinggi terdapat pada perlakuan dengan penambahan pupuk pelengkap $1 \mathrm{gL}^{-1}$, hal ini diduga karena dengan pemberian pupuk hayati yang terdapat kandungan

Tabel 3. Pengaruh Konsentrasi Pupuk Pelengkap terhadap Respirasi Tanah pada Pertanaman Bawang Putih 45 HST.

\begin{tabular}{cc}
\hline $\begin{array}{c}\text { Konsentrasi Pupuk Pelengkap } \\
(\text { Plant Catalyst })\end{array}$ & $\begin{array}{c}\text { Respirasi } \\
\mathrm{C}-\mathrm{CO}_{2}\left(\mathrm{~m} \mathrm{~g} \mathrm{jam}^{-1} \mathrm{~m}^{-2}\right)\end{array}$ \\
\hline $0 \mathrm{~g} \mathrm{~L}^{-1}\left(\mathrm{P}_{0}\right)$ & $24,70 \mathrm{c}$ \\
$0,5 \mathrm{~g} \mathrm{~L}^{-1}\left(\mathrm{P}_{1}\right)$ & $37,70 \mathrm{~b}$ \\
$1 \mathrm{~g} \mathrm{~L}^{-1}\left(\mathrm{P}_{2}\right)$ & $49,40 \mathrm{a}$ \\
$1,5 \mathrm{~g} \mathrm{~L}^{-1}\left(\mathrm{P}_{3}\right)$ & $30,22 \mathrm{c}$ \\
\hline BNT $(0,05)$ & 5,82 \\
\hline
\end{tabular}

Keterangan : Angka yang diikuti oleh huruf kecil yang sama tidak berbeda nyata dengan uji BNT pada taraf $5 \%$. 
mikroba seperti Azotobacter sp., Lactobacilliius sp., Azoprillium sp., mikroba pelarut fosfat sehingga jumlah mikroorganisme tanah meningkat dibandingkan tanpa pupuk hayati selain itu dengan penambahan konsentrasi pupuk pelengkap $1 \mathrm{~g} \mathrm{~L}^{-1}$ sudah dapat memberikan pengaruh yang baik terhadap mikrooganisme karena pupuk pelengkap mengandung unsur hara makro dan mikro yang efektif dalam menyerap pupuk utama dari dalam tanah dan dari pupuk dasar (Urea, P-36, KCl, ZA dan pupuk kandang). Unsur hara yang terkandung pupuk pelengkap melengkapi kebutuhan unsur hara yang tidak tersedia dari pupuk dasar sehingga meningkatkan aktivitas mikroorganisme dalam membantu penyerapan unsur hara.

Pengamatan 90 HST Interaksi antara pupuk hayati (B) dan pupuk pelengkap (P) tidak memberikan interaksi yang nyata terhadap respirasi tanah, hal ini diduga karena pengaruh perombakan bahan organik oleh mikroorganisme (Mulyani dkk., 1991). Menurunnya laju respirasi pada pengamatan $90 \mathrm{HST}$ dimungkinkan karena kandungan bahan organik yang semakin lama semakin menurun yang menyebabkan jumlah mikroorganisme yang ada didalam tanah menjadi sedikit. Selain itu persediaan sumber nutrisi dan mikroorganisme yang terdapat pada bahan organik menjadi berkurang, sehingga populasi dan aktivitas mikroorganisme menurun yang secara tidak langsung dapat menurunkan laju respirasi tanah.

Berdasarkan hasil analisis C-organik tanah (Tabel 5), padapengamatan 45 HST berkisar 3,38 \% $-3,73 \%$, kemudian pada pengamatan 90 HST berkisar 3,27\%-3,67\%. Kandungan C - organik tersebut termasuk dalam kriteria $\mathrm{C}$ - organik yang tinggi (Departemen Pertanian,1983 dalam Suhariyono dan Menry, 2005).

Kadar air tanah (Tabel 5), menunjukan bahwa pengamatan 45 HST berkisar 22,57\% - 30,17\% dan pada pengamatan $90 \mathrm{HST}$ berkisar 23,37\% - 29,18\%. Menurut Boyd (1993) kadar air berpengaruh terhadap proses dekomposisi yang berhubungan dengan kadar oksigen terlarut, semakin tinggi kadar air maka

Tabel 4. Pengaruh Pupuk Hayati (Bio max grow) dan Konsentrasi Pupuk Pelengkap (Plant catalyst) terhadap Respirasi Tanah pada Pertanaman Bawang Putih 45 HST.

\begin{tabular}{|c|c|c|c|c|}
\hline \multirow[t]{2}{*}{ Perlakuan } & \multicolumn{4}{|c|}{$\begin{array}{c}\text { Konsentrasi Pupuk Pelengkap } \\
\text { (Plant Catalyst })\end{array}$} \\
\hline & $\left(\mathrm{P}_{0}\right)$ & $0,5 \mathrm{~g} \mathrm{~L}^{-1}\left(\mathrm{P}_{1}\right)$ & $1 \mathrm{~g} \mathrm{~L}^{-1}\left(\mathrm{P}_{2}\right)$ & $1,5 \mathrm{~g} \mathrm{~L}^{-1}\left(\mathrm{P}_{3}\right)$ \\
\hline & & $\ldots . . \mathrm{C}-\mathrm{CO}_{2}$ & $\left.\mathrm{jam}^{-1} \mathrm{~m}^{-2}\right) \ldots$ & \\
\hline Tanpa Pupuk Hayati Bio Max & $24,05 \quad(\mathrm{~A})$ & $33,15(\mathrm{~B})$ & $35,10 \quad(\mathrm{~B})$ & 33,80 (A) \\
\hline Grow $\left(\mathrm{B}_{0}\right)$ & B & $\mathrm{a}$ & $\mathrm{a}$ & A \\
\hline Pupuk Hayati Bio Max Grow & $25,35(\mathrm{~A})$ & $42,25(\mathrm{~A})$ & 63,69 (A) & 26,65 (A) \\
\hline$\left(\mathrm{B}_{1}\right)$ & $\mathrm{c}$ & $\mathrm{b}$ & $\mathrm{a}$ & $\mathrm{C}$ \\
\hline BNT $(0,05)$ & & 8,23 & & \\
\hline
\end{tabular}

Keterangan: Nilai tengah yang diikuti oleh huruf yang sama tidak berbeda berdasarkan uji beda nyata terkecil (BNT) pada taraf 5\%, huruf kecil dibaca horizontal huruf kapital dibaca vertikal. 
Tabel 5. Data Hasil Pengamatan dan Ringkasan Analisis Ragam beberapa Sifat Kimia Tanah pada Lahan pertanaman Bawang Putih 45 HST dan 90 HST.

\begin{tabular}{|c|c|c|c|c|c|c|c|c|}
\hline \multirow[t]{2}{*}{ Perlakuan } & \multicolumn{2}{|c|}{$\begin{array}{c}\mathrm{C}-\underset{\text { organik }}{(\%)} \\
\end{array}$} & \multicolumn{2}{|c|}{$\begin{array}{c}\text { Kadar Air Tanah } \\
(\%)\end{array}$} & \multicolumn{2}{|c|}{$\begin{array}{c}\text { Suhu Tanah } \\
\left({ }^{\circ} \mathrm{C}\right)\end{array}$} & \multicolumn{2}{|c|}{$\begin{array}{c}\text { pH Tanah } \\
\left(\mathrm{H}_{2} \mathrm{O}\right)\end{array}$} \\
\hline & $45 \mathrm{HST}$ & $90 \mathrm{HST}$ & 45 HST & $90 \mathrm{HST}$ & $45 \mathrm{HST}$ & $90 \mathrm{HST}$ & $45 \mathrm{HST}$ & $90 \mathrm{HST}$ \\
\hline $\mathrm{B}_{0} \mathrm{P}_{0}$ & 3,32 & 3,30 & 30,17 & 29,18 & 24,01 & 24,31 & 6,21 & 6,24 \\
\hline $\mathrm{B}_{0} \mathrm{P}_{1}$ & 3,29 & 3,27 & 25,52 & 26,73 & 24,30 & 24,05 & 6,21 & 6,23 \\
\hline $\mathbf{B}_{0} \mathbf{P}_{2}$ & 3,47 & 3,47 & 23,76 & 24,70 & 24,49 & 24,49 & 6,20 & 6,22 \\
\hline $\mathrm{B}_{0} \mathrm{P}_{3}$ & 3,53 & 3,53 & 25,99 & 26,77 & 24,20 & 24,34 & 6,18 & 6,20 \\
\hline $\mathrm{B}_{1} \mathrm{P}_{0}$ & 3,68 & 3,37 & 25,00 & 26,13 & 24,02 & 24,51 & 6,14 & 6,17 \\
\hline $\mathrm{B}_{1} \mathrm{P}_{1}$ & 3,69 & 3,67 & 22,81 & 23,37 & 24,53 & 24,36 & 6,10 & 6,13 \\
\hline $\mathrm{B}_{1} \mathrm{P}_{2}$ & 3,73 & 3,50 & 22,57 & 23,80 & 24,85 & 24,89 & 6,10 & 6,13 \\
\hline $\mathrm{B}_{1} \mathrm{P}_{3}$ & 3,70 & 3,37 & 25,49 & 26,77 & 24,10 & 24,07 & 6,21 & 6,17 \\
\hline $\begin{array}{l}\text { Signifi } \\
\text { Kasi }\end{array}$ & \multicolumn{2}{|c|}{$\begin{array}{c}\mathrm{C}-\text { organik } \\
(\%)\end{array}$} & \multicolumn{2}{|c|}{$\begin{array}{c}\text { Kadar Air Tanah } \\
(\%)\end{array}$} & \multicolumn{2}{|c|}{$\begin{array}{c}\text { Suhu Tanah } \\
\left({ }^{\circ} \mathrm{C}\right)\end{array}$} & \multicolumn{2}{|c|}{ pH Tanah } \\
\hline & $45 \mathrm{HST}$ & $90 \mathrm{HST}$ & $45 \mathrm{HST}$ & $90 \mathrm{HST}$ & $45 \mathrm{HST}$ & $90 \mathrm{HST}$ & $45 \mathrm{HST}$ & $90 \mathrm{HST}$ \\
\hline B & $63,79^{*}$ & $1,52^{\mathrm{tn}}$ & $2,28^{\mathrm{tn}}$ & $1,14^{\mathrm{tn}}$ & $0,35^{\mathrm{tn}}$ & $0,74^{\mathrm{tn}}$ & $9,79^{*}$ & $9,39^{*}$ \\
\hline $\mathbf{P}$ & $3,02^{\mathrm{tn}}$ & $1,01^{\text {tn }}$ & $1,49^{\text {tn }}$ & $0,83^{\text {tn }}$ & $1,89^{\text {tn }}$ & $1,56^{\mathrm{tn}}$ & $0,19^{\text {tn }}$ & $0,35^{\text {tn }}$ \\
\hline $\mathrm{B} \times \mathrm{P}$ & $1,93^{\text {tn }}$ & $3,02^{\mathrm{tn}}$ & $0,42^{\text {tn }}$ & $0,23^{\mathrm{tn}}$ & $0,25^{\text {tn }}$ & $0,63^{\text {tn }}$ & $0,46^{\mathrm{tn}}$ & $0,37^{\mathrm{tn}}$ \\
\hline
\end{tabular}

Keterangan : $\mathrm{B}_{0}=$ tanpa pupuk hayati, $\mathrm{B}_{1}=$ dengan pupuk hayati, $\mathrm{P}_{0}=$ tanpapupuk pelengkap, $\mathrm{P}_{1}=$ pupuk pelengkap dengan konsentrasi $0,5 \mathrm{~g} \mathrm{~L}^{-1}, \mathrm{P}_{2}=$ pelengkap dengan konsentrasi $1 \mathrm{~g} \mathrm{~L}^{-1}, \mathrm{P}_{3}=$ pelengkap dengankonsentrasi $1,5 \mathrm{~g} \mathrm{~L}^{-1} ; \mathrm{tn}=$ tidak nyata; $*$ nyata pada taraf $5 \%$.

ketersediaan oksigen menjadi rendah dan akan menghambat proses dekomposisi aerob yang secara tidak langsung akan berpengaruh pada laju respirasi.

Berdasarkan pengukuran suhu (Tabel 5), ratarata pada pengamatan $45 \mathrm{HST}$ berkisar antara 24,01 $-24,85^{\circ} \mathrm{C}$ dan pengamatan $90 \mathrm{HST}$ berkisar $24,31^{\circ} \mathrm{C}$ $-24,89^{\circ} \mathrm{C}$. Menurut Hakim(1986), laju respirasi akan menjadi rendah pada suhu yang rendah dan akan meningkat pada suhu yang tinggi, faktor lainnya yang mempengaruhi adalah kelembaban tanah. Keluaran $\mathrm{CO}_{2}$ tanah yang biasanya rendah dalam kondisi kering karena rendahnya akar dan aktivitas mikroorganisme (Linn dan Doran, 1984).

Berdasakan hasil analisis $\mathrm{pH}$ tanah (Tabel 5), pada pengamatan 45 HST berkisar $6,10-6,21$ dan pengamatan 90 HST berkisar 6,13 - 6,24, menunjukkan bahwa hanya pada perlakuan pupuk hayati saja yang menunjukkan pengaruh yang nyata pada 45 HST maupun 90 HST.Perlakuan tanpa pupuk hayati menghasilkan $\mathrm{pH}$ tanah lebih tinggi dibandingkan pemberian pupuk hayati.Hal ini diduga karena pupuk hayati BMG mengandung mikroba pelarut fosfat yang dapat menurunkan $\mathrm{pH}$ tanah.Menurut Penelitian Islamiati (2015) bakteri Azotobacter sp. kandungan yang terdapat dalam Biomax Grow berpotensi sebagai pelarut fosfat karena dapat menghasilkan asam organik sehingga dapat melarutkan fosfat dari sumber yang telah tersedia. Bakteri pelarut fosfat adalah bakteri yang dapat melarutkan fosfat yang tidak dapat terlarut dengan cara mensekresi asam organik. Peningkatan asam organik tersebut akan menurunkan $\mathrm{pH}$ tanah yang penting dalam peningkatan kelarutan fosfat (Thomas, 1985).

Hasil uji korelasi pada pengamatan 45 HST menunjukkan bahwa perlakuan pupuk hayati dan pemberian konsentrasi pupuk pelengkap tidak 
Tabel 6. Pengaruh Pupuk Hayati terhadap C - organik Tanah pada Pertanaman Bawang Putih 45 HST.

\begin{tabular}{lc}
\hline \multicolumn{1}{c}{ Perlakuan } & C - organik (\%) \\
\hline Tanpa Pupuk Hayati Bio Max Grow $\left(\mathrm{B}_{0}\right)$ & $3,40 \mathrm{~b}$ \\
Pupuk Hayati Bio Max Grow $\left(\mathrm{B}_{1}\right)$ & $3,70 \mathrm{a}$ \\
\hline BNT $(0,05)$ & 0,08 \\
\hline
\end{tabular}

Keterangan : Angka yang diikuti oleh huruf kecil yang sama tidak berbeda nyata dengan uji BNT pada taraf $5 \%$.

Tabel 7. Pengaruh Pupuk Hayati terhadap pH Tanah pada Pertanaman Bawang Putih 45 HST.

\begin{tabular}{lc}
\hline \multicolumn{1}{c}{ Perlakuan } & pH Tanah $\left(\mathrm{H}_{2} \mathrm{O}\right)$ \\
\hline Tanpa Pupuk Hayati Bio Max Grow $\left(\mathrm{B}_{0}\right)$ & $6,20 \mathrm{a}$ \\
Pupuk Hayati Bio Max Grow $\left(\mathrm{B}_{1}\right)$ & $6,12 \mathrm{~b}$ \\
\hline BNT $(0,05)$ & 0,05 \\
\hline Ke
\end{tabular}

Keterangan : Angka yang diikuti oleh huruf kecil yang sama tidak berbeda nyata dengan uji BNT pada taraf $5 \%$.

Tabel 8. Pengaruh Pupuk Hayati terhadap pH Tanah pada Pertanaman Bawang Putih 90 HST.

\begin{tabular}{|c|c|}
\hline Perlakuan & $\begin{array}{c}\mathrm{pH} \text { Tanah } \\
\left(\mathrm{H}_{2} \mathrm{O}\right)\end{array}$ \\
\hline Tanpa Pupuk Hayati Bio Max Grow $\left(\mathrm{B}_{0}\right)$ & $6,22 \mathrm{a}$ \\
\hline Pupuk Hayati Bio Max Grow $\left(\mathrm{B}_{1}\right)$ & $6,15 \mathrm{~b}$ \\
\hline $\operatorname{BNT}(0,05)$ & 0,05 \\
\hline
\end{tabular}

Keterangan: Angka yang diikuti oleh huruf kecil yang sama tidak berbeda nyata dengan uji BNT pada taraf $5 \%$.

menunjukkan korelasi antara respirasi tanah dengan $\mathrm{C}$ - organik, kadar air tanah, dan suhu tanah. Pada pengamatan 90 HST menunjukkan bahwa pemberian pupuk hayati dan perlakuan konsentrasi pupuk pelengkap tidak menunjukkan korelasi antara respirasi tanah dengan $\mathrm{C}$ - organik tanah, kadar air tanah, $\mathrm{pH}$ tanah dan suhu tanah. Korelasi antara $\mathrm{pH}$ tanah dengan respirasi tanah menunjukkan korelasi negatif pada pengamatan $45 \mathrm{HST}$, artinya semakin tinggi $\mathrm{pH}$ tanah maka respirasi tanah semakin rendah (pada kisaran $\mathrm{pH}$ 6,08 hingga 6,31). Hal ini tidak sesuai yang disampaikan Hasibuan dan Ritonga (1981), yang menyatakan bahwa aktivitas jasad renik akan menurun dengan menurunnya $\mathrm{pH}$ tanah.

Berdasarkan Uji BNT 5\% (Tabel 6), menunjukkan bahwa pemberian pupuk hayati nyata memberikan nilai C - organik lebih tinggi dibandingkan tanpa pupuk hayati. Hal ini diduga karena bahan organik akan menjadi tidak berguna tanpa adanya mikroorganisme yang dapatmenguraikan. Pupuk hayati mengandung mikroba yang beperan dalam perombakan bahan organik yaitu salah satunya Pseudomonas sp. yang memiliki kemampuan untuk mempercepat pengomposan dan meningkatkan mutu kompos, jumlah 
Tabel 9. Uji korelasi antara C - organik tanah, pH Tanah, Kadar Air Tanah, dan Suhu Tanah dengan Respirasi Tanah.

\begin{tabular}{lcc}
\hline \multirow{2}{*}{\multicolumn{1}{c}{ Amatan }} & \multicolumn{2}{c}{ Koefisien Korelasi $(\mathrm{r})$} \\
\cline { 2 - 3 } & \multicolumn{2}{c}{ Respirasi Tanah } \\
\cline { 2 - 3 } C-Organik $(\%)$ & 45 HS T & 90 HS T \\
pH Tanah $\left(\mathrm{H}_{2} \mathrm{O}\right)$ & $0,399^{\text {tn }}$ & $0,378^{\text {tn }}$ \\
Suhu Tanah $\left({ }^{\circ} \mathrm{C}\right)$ & $0,408^{*}$ & $0,121^{\text {tn }}$ \\
Kadar Air Tanah $(\%)$ & $0,379^{\text {tn }}$ & $0,225^{\text {tn }}$ \\
\hline
\end{tabular}

Keterangan: $\mathrm{tn}=$ tidak nyata; $*=$ nyata pada taraf $5 \%$; HST $=$ hari setelah tanam

dan jenis mikoorganisme menentukan keberhasilan proses dekomposi atau pengomposan, sehingga semakin tinggi $\mathrm{C}$-organik tanah maka aktivitas mikroorganisme meningkat. Kandungan C - organik pada pengamatan 45 HST berkisar 3,38 \% - 3,73\%, kemudian pada pengamatan 90 HST berkisar 3,27\%3,67\%. Kandungan $\mathrm{C}$ - organik tersebut termasuk dalam kriteria C - organik yang tinggi (Departemen Pertanian,1983 dalam Suhariyono dan Menry, 2005). Berdasarkan Uji BNT 5\% (Tabel 7) dan (Tabel 8), menunjukkan bahwa perlakuan tanpa pupuk hayati pada 45 HST nyata memberikan nilai $\mathrm{pH}$ tanah yang lebih tinggi dibandingkan tanpa pemberian pupuk hayati. Hal ini dikarenakan pupuk hayati BMG mengandung mikroba pelarut fosfat yang dapat menurunkan $\mathrm{pH}$ tanah. Menurut Penelitian Islamiati (2015) bakteri Azotobacter sp. kandungan yang terdapat dalam Biomax Grow berpotensi sebagai pelarut fosfat karena dapat menghasilkan asam organik sehingga dapat melarutkan fosfat dari sumber yang telah tersedia. Bakteri pelarut fosfat adalah bakteri yang dapat melarutkan fosfat yang tidak dapat terlarut dengan cara mensekresi asam organik. Peningkatan asam organik tersebut akan menurunkan $\mathrm{pH}$ tanah yang penting dalam peningkatan kelarutan fosfat (Thomas, 1985).

\section{KESIMPULAN}

Kesimpulan dari hasil penelitian ini yaitu Perlakuan pupuk hayati Bio Max Grow $\left(10 \mathrm{ml} \mathrm{L}^{-1}\right)$ menghasilkan nilai respirasi tanah yang lebih tinggi dibandingkan tanpa pupuk hayati Bio Max Grow pada pengamatan 45 HST sedangkan pada pengamatan 90 HST tidak adanya pengaruh pada perlakuan pupuk hayati maupun tanpa pupuk hayati. Pemberian pupuk hayati menurunkan $\mathrm{pH}$ tanah dan berkorelasi negatif dengan respirasi tanah pada pengamatan 45 HST. Pemberian pupuk pelengkap Plant Catalyst memberikan pengaruh yang berbeda, konsentrasi pupuk pelengkap $1 \mathrm{~g} \mathrm{~L}^{-1}\left(\mathrm{P}_{2}\right)$ menghasilkan nilai respirasi tanah yang lebih tinggi dan diikuti oleh konsentrasi pupuk pelengkap $0,5 \mathrm{~g} \mathrm{~L}^{-1}\left(\mathrm{P}_{1}\right)$, sedangkan konsentrasi pupuk pelengkap 1,5 $\mathrm{g} \mathrm{L}^{-1}\left(\mathrm{P}_{3}\right)$ dan tanpa pupuk pelengkap $\left(\mathrm{P}_{0}\right)$ tidak berbeda pada pengamatan 45 HST. Terdapat interaksi antara pemberian pupuk hayati dan konsentrasi pupuk pelengkap pada respirasi tanah dipengamatan 45 HST. Perlakuan tanpa pupuk 
hayati menghasilkan nilai respirasi yang tidak berbeda pada konsentrasi pupuk pelengkap $\left(\mathrm{P}_{1}\right) 0,5 \mathrm{gL}^{-1},\left(\mathrm{P}_{2}\right) 1$ $\mathrm{g} \mathrm{L}^{-1}$ dan $\left(\mathrm{P}_{3}\right)$ 1,5 $\mathrm{g} \mathrm{L}^{-1}$ dan berbeda nyata pada konsentrasi $\left(\mathrm{P}_{0}\right) 0 \mathrm{~g} \mathrm{~L}^{-1}$, sedangkan perlakuan pupuk hayati menghasilkan nilai respirasi tertinggi pada konsentrasi $\left(\mathrm{P}_{2}\right) 1 \mathrm{~g} \mathrm{~L}^{-1}\left(63,69 \mathrm{mg} \mathrm{jam}^{-1} \mathrm{~m}^{-2}\right)$ yang diikuti dengan $\left(\mathrm{P}_{1}\right) 0,5 \mathrm{~g} \mathrm{~L}^{-1}$ dan konsentrasi $\left(\mathrm{P}_{0}\right) 0 \mathrm{~g} \mathrm{~L}^{-1}$ dan $\left(\mathrm{P}_{3}\right) 1,5 \mathrm{~g} \mathrm{~L}^{-1}$ menunjukkan nilai yang tidak berbeda.

\section{DAFTAR PUSTAKA}

Badan Pusat Statistik. 2015. Luas Panen Bawang Putih Menurut Provinsi, 2012-2016. Direktorat Jenderal Hortikultura.

Boyd, C.E. 1993. Shrimp Pond Bottom Soil and Sedimen Managemen. U.S.Wheat Assosiaties.Singapore, $255 \mathrm{p}$.

Hajoeningtijas, O., D. 2005. Mikro Biologi Pertanian. Graha Ilmu. Jakarta.

Hakim, N., Y.M. Nyakpa, A.M. Lubis, S.G. Nugroho, M.R. Saul, M.A. Dika, G. Ban-Hong, dan H.H. Bailey. 1986. Dasar-dasar Ilmu Tanah.Universitas Lampung. Jakarta. $488 \mathrm{hlm}$.

Hanafiah, A.S., T. Sabrina dan H. Guchi. 2005. Biologi dan Ekologi Tanah.Program Studi Agroteknologi Fakultas Pertanian.

Hasibuan B. E., M. D. Ritonga. 1991. Ilmu Tanah Umum. Fakultas PertanianUSU. Medan.

Islamiati, A. dan Zulaika, E. 2015. Pengaruh Azotobacter sp. sebagai Pelarut Fosfat. Jurnal Sains dan Seni Pomits. 2 (1) : 8 - 17.
Khan. T.A., M. Mazid., dan F. Mohammad. 2011. A review of ascorbic acidpotentialities against oxidative stress induced in plants. Journal ofAgrobiology. 28(2): 97-111.

Linn, D dan Doran, JW. 1984. Tillage Effects on Carbon Sequestration and Microbial Biomassin Reclaimed Farmland Soils of Southwestern Indiana. Soil Sci.Society.48: 1267-1272.

Mulyani, M.S., A.G. Kartosapoetro, dan R.D.S. Sastroatmojo. 1991. MikrobiologiTanah. Rineka Cipta. Jakarta. 447 hlm.

Sarwadana, S.M. dan I. G. A. Gunadi. 2007. Potensi Pengembangan BawangPutih (Allium sativum L.) Dataran Rendah Varietas Lokal Sanur. Agritop. 26 (1) : 19 - 23.

Suhariyono, G., dan Menry, Y. 2005.Analisis Karakteristik Unsur-unsur dalamTanah di Berbagai Lokasi dengan Menggunakan $X R F$. PuslitbangTeknologi Maju. Yogyakarta.

Thomas, G.V. 1985. Occurence and Availibility Of Phosphate-Solubilizing Fungi From Coconut. Plant Soil.87 : 57-364. 